Zeszyty Naukowe Szkoły Głównej Gospodarstwa Wiejskiego w Warszawie

Problemy Rolnictwa Światowego tom 20 (XXXV), zeszyt 1, 2020: 5-14

DOI: 10.22630/PRS.2020.20.1.1

Karolina Babuchowska ${ }^{1}$

Uniwersytet Warmińsko-Mazurski w Olsztynie

\title{
Wpływ zniesienia kwot mlecznych na funkcjonowanie gospodarstw specjalizujących się w produkcji mleka ${ }^{2}$
}

\section{Impact of the Abolition of Milk Quotas on the Functioning of Dairy Farms}

\begin{abstract}
Synopsis. Rynek mleka od początku integracji europejskiej należał do najbardziej uregulowanych. Jednym w kluczowych instrumentów, które miały zapewnić jego stabilizację były wprowadzone w 1984 r. kwoty mleczne. Dążąc do większej liberalizacji rynku mleka UE zdecydowała o zniesieniu od 1 kwietnia 2015 r. limitów produkcji. Fakt ten znacząco zmienił warunki funkcjonowania gospodarstw specjalizujących się $\mathrm{w}$ produkcji mleka. Celem artykułu była próba ukazania jak zniesienie limitowania produkcji mleka wpłynęło na funkcjonowanie polskich gospodarstw mleczarskich. Podstawowym źródeł informacji były wyniki badań ankietowych przeprowadzonych wśród 1047 właścicieli gospodarstw specjalizujących się w produkcji mleka. Informacje te uzupełniono danymi Agencji Rynku Rolnego, Głównego Urzędu Statystycznego oraz Eurostat. W opinii ponad połowy respondentów na skutek likwidacji w 2015 r. kwot mlecznych pogorszyła się sytuacja ich gospodarstwa. Wynikało to przede wszystkim z niskich cen mleka, które wpłynęły na obniżenie opłacalności produkcji. Z tego wzgledu aż $62 \%$ badanych było zdania, że na rynku mleka powinien być większy stopień interwencji.
\end{abstract}

Slowa kluczowe: produkcja mleka, gospodarstwa rolne, zniesienie kwot mlecznych

\begin{abstract}
The milk market was one of the most regulated since the beginning of European integration. One of the key instruments to stabilize this market was milk quota. It was introduced in 1984. Aiming at greater milk market liberalization, the EU decided to lift limits of the production from 1 April 2015. This fact significantly changed the operating conditions of dairy farms. The aim of the article was to show how the implementation (along with Poland's accession to the EU), and then the abolition of milk production, affected the situation of Polish dairy farms. The primary sources of information were the results of a survey in 1047 dairy farm owners operating throughout the country. This information was supplemented by Agriculture Market Agency and Milk Market Observatory data. In the opinion of more than half of the respondents, as a result of the abolition of milk quotas in 2015 , the situation of their farms worsted. This fact was primarily due to the low prices of raw milk, which was driven by lower efficiency of production. As a result, $62 \%$ of the respondents believed that there should be a greater degree of intervention on the milk market.
\end{abstract}

Key words: dairy production, farms, the abolition of milk quotas

JEL Classification: Q18

\footnotetext{
1 dr, ul. Oczapowskiego 4, 10-719 Olsztyn, e-mail: karolina.babuchowska@uwm.edu.pl, https://orcid.org/0000-0002-9053-7842

2 Projekt został sfinansowany ze środków Narodowego Centrum Nauki przyznanych na podstawie decyzji numer DEC-2011/03/D/HS4/04248
} 


\section{Wprowadzenie}

Produkcja mleka jest bardzo ważną częścią gospodarki żywnościowej zarówno w Polsce, jak i w wielu innych krajach Unii Europejskiej. Szacuje się, że w 28 krajach Wspólnoty w 2018 r. wyprodukowano 172,2 mln t mleka, w tym produkcja mleka krowiego $^{3}$ wyniosła 166,6 $\mathrm{mln} \mathrm{t}^{4}$. O szczególnym znaczeniu mleka w gospodarce żywnościowej decyduje nie tylko jego wysoki udział w produkcji towarowej, ale także fakt, że zarówno mleko, jak i przetwory mleczne, będąc cennym źródłem białka, witamin i składników mineralnych, posiadają wyjątkowe walory żywieniowe, które trudno jest substytuować (Gornowicz, 2003).

Rynek mleka należy do najbardziej uregulowanych rynków sektora żywnościowego w Unii Europejskiej. Pierwsze interwencje wewnętrzne na rynku mleka zostały wprowadzone pod koniec lat 60. XX w., towarzyszyły im także określone regulacje handlowe. W pierwszej kolejności w 1964 r. utworzono wspólną organizację rynku mleka i jego przetworów, następnie w 1968 r. wprowadzono system jednolitych cen rolnych na mleko i produkty mleczarskie (Czyżewski, Guth, 2016). Głównym celem wdrożonych regulacji było ustabilizowanie rynku mleka przy poziomie cen zapewniającym opłacalność produkcji. Efekt ten udało się dość szybko osiagnąć, jednak w krótkim czasie wysokie ceny mleka pozwoliły nie tylko na zlikwidowanie niedoborów na rynku, ale przyczyniły się do powstania nadwyżek, które coraz trudniej było zagospodarować. Popyt wewnętrzny na mleko i jego przetwory rósł bowiem dużo wolniej niż podaż. W efekcie koniczne było subsydiowanie zarówno eksportu, jak i sprzedaży na rynku wspólnotowym. W tej sytuacji, aby zapobiec destabilizacji na rynku, niezbędne było wprowadzenie instrumentu, który lepiej dostosuje tempo wzrostu produkcji do zapotrzebowania. W konsekwencji w $1984 \mathrm{r}$. zdecydowano się na zastosowanie systemu administracyjnego limitowania podaży mleka, tzw. kwot mlecznych. Ich celem było zlikwidowanie nadwyżek strukturalnych, wynikających z braku równowagi pomiędzy podażą a popytem na mleko i przetwory mleczne. Ponadto wprowadzono system opłat karnych za przekroczenie indywidualnych kwot mlecznych (Grochowska, 2003). Wielkość kary ściśle powiązano z cenami mleka i kosztami produkcji. Kara ustalana była na wysokim poziomie - tak, że przychód z tytułu dodatkowo wyprodukowanej i sprzedanej jednostki produktu, pomniejszony o wysokość kary nie pokrywał kosztów krańcowych. W rezultacie prowadziło to do ograniczenia produkcji (Hamulczuk, Stańko, 2009).

Jak wyjaśniają Baer-Nawrocka i Kiryluk-Dryjska (2010) ograniczenie produkcji kwotami ma sens ekonomiczny wówczas, gdy ceny wewnętrzne są wyższe od cen światowych, a wielkość produkcji przy danym poziomie cen przewyższa popyt wewnętrzny. Trudności ze zbytem produktów na rynkach światowych są bowiem odpowiednią przesłanką, aby produkcję ograniczyć. Kwotowanie produkcji, obok pozytywnych, wywołuje także negatywne skutki. Do takich należy ograniczenie bodźców stymulujących poprawę efektywności ekonomicznej gospodarstw. Ponadto w przypadku kwot niezbędne jest administrowanie nimi, co generuje dodatkowe koszty.

Wprowadzony na rynku mleka system kwotowy przyczynił się tylko do nieznacznego spadku podaży, konieczne było więc wprowadzenie innych regulacji. W zależności od

\footnotetext{
3 Oprócz mleka krowiego w krajach UE-28 wyprodukowano w 2018 r. ok. 5,2 mln t mleka owiec, kóz i bawołów. ${ }^{4} \mathrm{https}$ ://ec.europa.eu/eurostat/statistics-explained/index.php/Milk_and_milk_product_statistics\#Milk_production, dostęp: 30.01 .2020
} 
sytuacji na rynku mleka system interwencji był wielokrotnie zmieniany i uwzględniał równoległe stosowanie kilku rozwiązań (np.: kwot produkcji, bezpośredniego wsparcia dochodów rolników, instrumentów wspierających rynek wewnętrzny, instrumentów regulujących handel zagraniczny), jednak do końca lat 90. nie przeszedł gruntownej zmiany (Szajner, 2010). Dopiero w 1999 r., podczas Agendy 2000, zdecydowano o jego zasadniczej przebudowie. Podjęto m.in. decyzję o przedłużeniu systemu kwotowania produkcji mleka do $2003 \mathrm{r}$. oraz stopniowym wzroście kwot mlecznych (o 1,5\% rocznie w latach 2005-2008) (Grochowska, 2003). Głównym kierunkiem wprowadzanych zmian była liberalizacja sektora oraz uzależnienie go od sytuacji na rynkach światowych.

Mimo oczekiwań europejskich rolników związanych z utrzymaniem systemu kwot, jako gwarancji wysokich cen skupu mleka (Śmigla, 2013), ostatecznie podczas przeglądu wspólnej polityki rolnej w 2008 r. zapadła decyzja o ich zniesieniu w 2015 r. W ten sposób, po ponad 30 latach zarządzania rynkiem przez system kwot mlecznych, 1 kwietnia $2015 \mathrm{r}$. przestały one obowiązywać.

Aby ułatwić producentom mleka funkcjonowanie w zmieniających się warunkach, zdecydowano się na zwiększenie kwot mlecznych we wszystkich państw UE o $1 \%$ w kolejnych latach kwotowych począwszy od roku 2009/2010 a skończywszy na 2013/2014 (Parzonko, 2013). Ponadto w 2012 r. wprowadzono tzw. pakiet mleczny, którego zadaniem było wzmocnienie pozycji producentów w łańcuchu dostaw przetworów mlecznych. W pakiecie zalecono m.in. wprowadzenie w krajach członkowskich UE pisemnych umów kontraktacyjnych na dostawy mleka, zawieranych między producentami surowca a jego odbiorcami. Takie rozwiązanie ma $\mathrm{z}$ jednej strony zminimalizować ryzyko cenowe, $\mathrm{z}$ drugiej - stanowi formę kontroli podaży mleka na rynku. Wzmocnienie pozycji producentów mleka ma $\mathrm{z}$ kolei nastąpić poprzez ich integrację $\mathrm{w}$ formie zarejestrowanych organizacji producentów, które są odpowiedzialne za zbiorowe negocjowanie umów na dostawy mleka (Rozporządzenie, 2012).

Z opublikowanego w listopadzie 2016 r. sprawozdania Komisji Europejskiej wynika, że zaproponowane w pakiecie mlecznym rozwiązania sprawdzają się głównie w obszarze dwóch kluczowych instrumentów jakimi są organizacje producentów mleka oraz zbiorowe negocjowanie umów. Ich potencjał nie jest jednak w pełni wykorzystany. Z tego względu zalecono podjęcie działan o charakterze finansowym, informacyjnym czy też operacyjnym, których celem jest wzmocnienie zaproponowanych rozwiązań (Report, 2016).

$\mathrm{W}$ obliczu ogromnych zmian, z jakim musieli się zmierzyć polscy producenci mleka $\mathrm{W}$ ostatnich kilkunastu latach, celem podjętych $\mathrm{w}$ artykule rozważań jest próba ukazania jak zniesienie limitów w produkcji mleka jest postrzegane przez rolników specjalizujących się w produkcji mleka oraz jak wpłynęło na funkcjonowanie ich gospodarstw.

\section{Materiał i metody}

Głównym źródłem informacji wykorzystanym w artykule były dane pierwotne zgromadzone metodą ankietową $\mathrm{z}$ zastosowaniem autorskiego kwestionariusza. Kwestionariusz zawierał 36 rozbudowanych pytań (dotyczących m.in.: charakterystyki prowadzonego gospodarstwa oraz realizowanej produkcji, oceny uwarunkowań prowadzenia działalność, realizowanych inwestycji ze szczególnym uwzględnieniem wprowadzanych innowacji, kapitału ludzkiego) oraz metryczkę. Ze względu na rozległy obszar badań (cała Polska) były one realizowane od II kw. 2015 r., a zakończyły się w I kw. 
2016 r. Łącznie pozyskano informacje od 1047 producentów mleka ${ }^{5}$, prowadzących działalność na terenie wszystkich województw. Tłem rozważań było ukazanie zmian, które nastapiły na rynku mleka od momentu przystapienia Polski do UE. W tym celu wykorzystano dane Agencji Rynku Rolnego (ARR), Głównego Urzędu Statystycznego (GUS) oraz Eurostat.

Zebrany materiał źródłowy poddano opracowaniu statystycznemu, a do prezentacji wyników zastosowano metodę graficzną i opisową.

\section{Wyniki badań}

Nie ulega wątpliwości, że po integracji znacząco zmieniły się w Polsce uwarunkowania produkcji mleka. Uczestnictwo w jednolitym rynku europejskim zwiększyło presję przemysłu rolno-spożywczego na dostawy jednolitych partii surowca o wystandaryzowanej jakości. Wymagania jakościowe $\mathrm{w}$ produkcji mleka z jednej strony przyspieszyły proces modernizacji gospodarstw, z drugiej - od początku integracji obserwuje się postępującą koncentrację tej produkcji (Parzonko, 2014; Sadowski, Michalczak, 2015).

Jak wynika z danych Agencji Rynku Rolnego liczba hurtowych dostawców mleka w pierwszym roku kwotowym (2004/2005) wynosiła ponad 311 tys., natomiast w przypadku dostawców bezpośrednich było to nieco ponad 76 tys. (rys. 1).

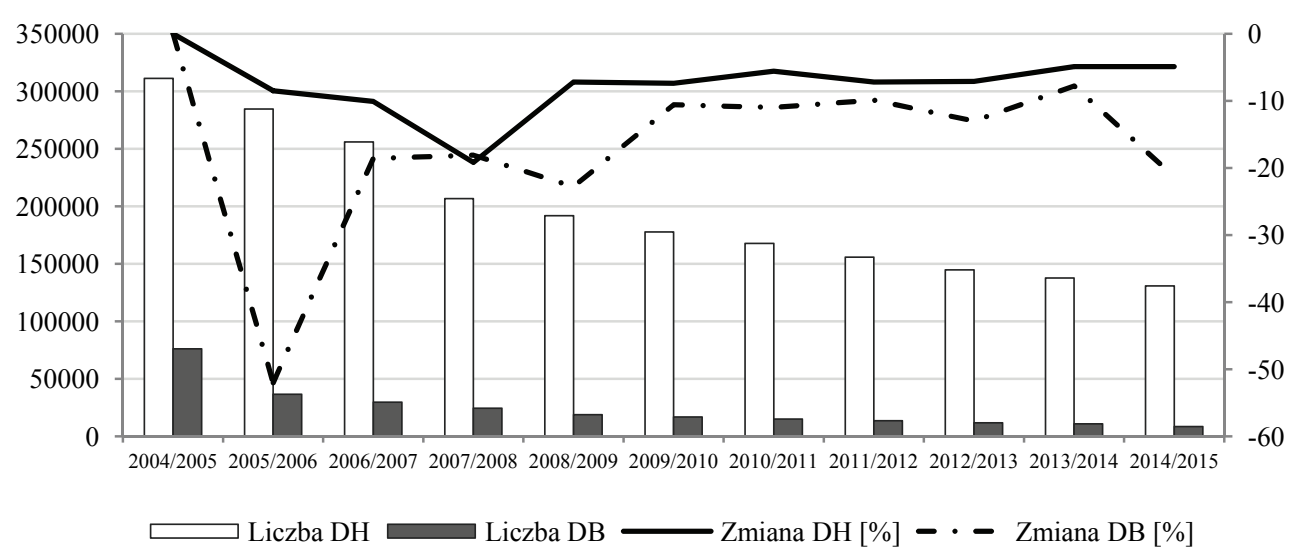

* DH - dostawcy hurtowi, DB - dostawcy bezpośredni

Rys. 1. Liczba hurtowych i bezpośrednich dostawców mleka w Polsce i dynamika jej zmian Fig. 1. Number of wholesale and direct suppliers of milk in Poland and dynamics of changes

Źródło: opracowanie własne na podstawie danych ARR.

\footnotetext{
5 Prezentowane w artykule wyniki stanowią niewielki fragment badań przeprowadzonych w ramach projektu $\mathrm{NCN}$, ,Rola wspólnej polityki rolnej w procesie unowocześniania polskiego rolnictwa na przykładzie produkcji mleka finansowany ze środków". Na etapie konstruowania próby badawczej dołożono wszelkich starań, aby uzyskane wyniki pozwoliły na uogólnienie wniosków. W związku z tym, w oparciu o dane Agencji Rynku Rolnego dotyczące liczby hurtowych i bezpośrednich dostawców mleka, obliczono wielkość próby badawczej (wykorzystano wzór zaproponowany przez Szreder 2004, s. 121), a następnie zastosowano alokację proporcjonalną, która pozwoliła na określenie ile gospodarstw należy objąć badaniem w poszczególnych województwach.
} 
W przekroju regionalnym największa liczba hurtowych dostawców mleka występowała w województwach: mazowieckim (69825), lubelskim (44270) oraz łódzkim (42994). W przypadku dostawców bezpośrednich najwięcej zarejestrowano w województwach: małopolskim (14094) i podkarpackim (133363). W każdym kolejnym roku kwotowym liczba, zarówno jednych, jak i drugich dostawców zmniejszała się, przy czym w kolejnych latach kwotowych zdecydowanie większe ubytki odnotowano w grupie dostawców bezpośrednich. Ich liczba już w drugim roku kwotowym w porównaniu do pierwszego była niższa o $52 \%$. W ostatnim roku kwotowym (2014/2015) funkcjonowało w Polsce łącznie 8497 dostawców bezpośrednich, w tym ponad 2 tys. w woj. małopolskim. W przypadku liczby hurtowych dostawców mleka spadki były dużo niższe (największy - o 19,2\%, nastapił w roku 2007/2008). Ostatecznie w roku 2014/2015 było ich 130816, najwięcej w województwach mazowieckim, podlaskim i łódzkim ${ }^{6}$.

Mimo znacznej redukcji liczby dostawców mleka oraz pogłowia krów, od początku integracji i wprowadzenia systemu kwot obserwowano w Polsce wzrost produkcji mleka Było to możliwe dzięki znacznej poprawie wydajności krów (Seremak-Bulge, Roman, 2016). Ponadto wzrost ilości surowca dostarczanego przez producentów mleka był także efektem wyższej opłacalności produkcji oraz większych możliwości produkcyjnych związanych z procesem restrukturyzacji i modernizacji gospodarstw ${ }^{7}$.

Jak wynika z danych zaprezentowanych na rysunku 2 średnia ilość mleka dostarczana przez dostawców hurtowych do podmiotów skupujących wzrosła z $26828 \mathrm{~kg}$ w roku 2004/2005 do $80307 \mathrm{~kg} \mathrm{w}$ ostatnim roku kwotowym. W przypadku ilości mleka wprowadzonej do obrotu przez dostawców bezpośrednich zaobserwowano spadek z prawie $309 \mathrm{mln} \mathrm{kg} \mathrm{(w} \mathrm{roku} \mathrm{2004/2005)} \mathrm{do} \mathrm{nieco} \mathrm{ponad} 48 \mathrm{mln} \mathrm{kg} \mathrm{(w} \mathrm{roku} \mathrm{2014/2015).}$

Produkcja mleka jest trudnym kierunkiem produkcji rolniczej. W porównaniu do innych rodzajów działalności wymaga od rolnika bardzo dużego zaangażowania i dyspozycyjności. Mimo to wiele polskich gospodarstw po integracji naszego kraju z Unią Europejską zaczęło się specjalizować właśnie w produkcji mleka. Na podstawie wyników badań ankietowych stwierdzono, że o wyborze tego kierunku produkcji wśród objętych badaniami producentów mleka zdecydowały różne przesłanki. W ponad $77 \%$ wynikało to $\mathrm{z}$ tradycji rodzinnej, producenci rolni kontynuowali bowiem produkcję, którą wcześniej zajmowali się rodzice lub poprzedni właściciele gospodarstwa. Stosunkowo wysoki był także odsetek osób (40,69\%), które argumentowały decyzję o specjalizacji w produkcji mleka jego opłacalnością. Respondenci wśród przyczyn zdecydowanie rzadziej $(10,60 \%)$ wskazywali dobre przygotowanie zawodowe.

\footnotetext{
${ }^{6}$ Proces zmniejszania się liczby gospodarstw zajmujących się chowem krów mlecznych i produkcją mleka na sprzedaż obserwowany był nie tylko w Polsce, ale także w innych krajach UE. Z badań przeprowadzonych przez Parzonko (2016b) wynika, że liczba dostawców hurtowych w latach kwotowych 2004/2005-2014/2015 zmniejszyła się w 24 krajach Wspólnoty, przy czym największe spadki odnotowano na Litwie, Łotwie, w Portugalii, Estonii i Polsce.

7 Wśród ankietowanych 93,1\% przeprowadziło w latach 2004-2014 inwestycje. Wiele z nich wynikało z konieczności dostosowania gospodarstwa do wymogów UE, w tym zapewnienia odpowiednich warunków sanitarno-weterynaryjnych, bezpieczeństwa produkcji, ochrony środowiska, dobrostanu zwierząt.
} 


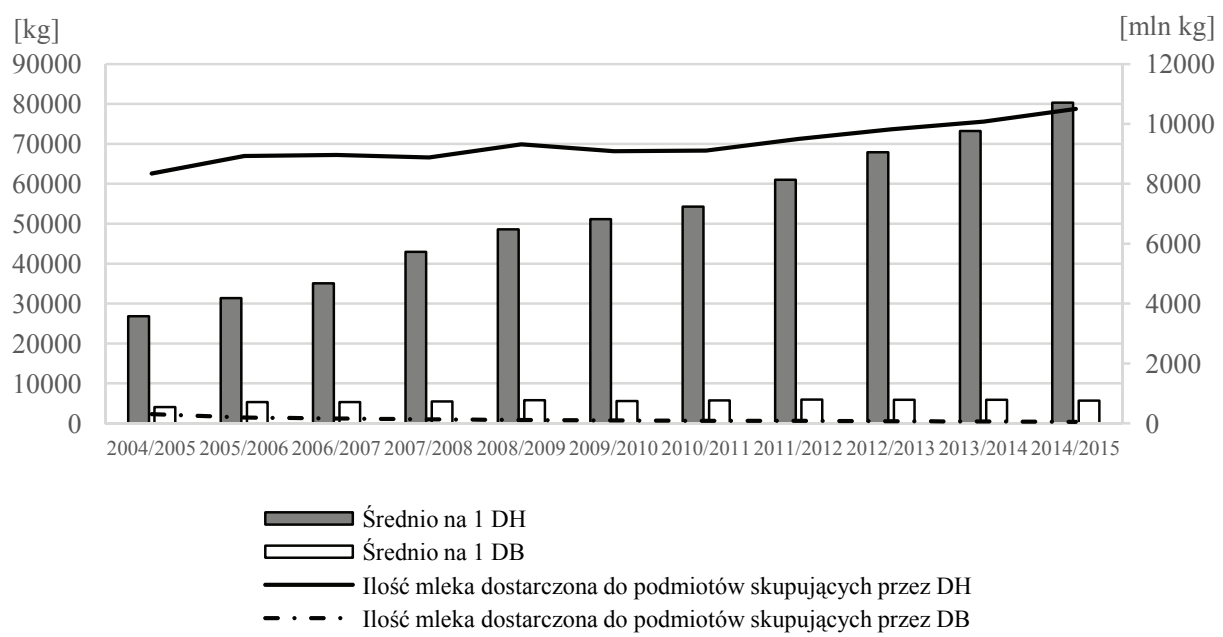

Rys. 2. Ilość mleka dostarczona do podmiotów skupujących przez dostawców hurtowych i wprowadzona do obrotu przez dostawców bezpośrednich w poszczególnych latach kwotowych (kg w thuszczu referencyjnym)

Fig. 2. The milk quantity delivered to the purchaser by wholesale and direct suppliers (in kilograms of reference)

Źródło: opracowanie własne na podstawie danych ARR.

Należy zauważyć, że nowe uwarunkowania produkcji mleka, jakie nastąpiły tuż po integracji z UE nie były łatwe dla polskich rolników. Szczególnie wiele wątpliwości mieli producenci mleka, wynikało to m.in. z kłopotów, jakie mieli z utrzymaniem przyznanych kwot, a także karami, którymi ich obciążano za przekroczenie limitów. Mimo to opinie ankietowanych na temat warunków funkcjonowania gospodarstwa tuż po integracji były raczej pozytywne (44,09\% stwierdziło poprawę w porównaniu do warunków przed 2004 r.). Nieznacznie wyższy $(44,96 \%)$ był udział respondentów, którzy stwierdzili poprawę ogólnej sytuacji na rynku mleka po 2004 r. (rys. 3). Odmienne były opinie rolników na temat warunków prowadzenia działalności po likwidacji kwot w 2015 r. W tym przypadku około połowa producentów mleka objętych badaniami $(50,43 \%)$ zmianę tę postrzegała jako niekorzystną.

Tak wysoki odsetek wskazań stwierdzających pogorszenie warunków funkcjonowania gospodarstwa po zlikwidowaniu kwot mlecznych wynikać może z ogólnej sytuacji, jaką od 2014 r. obserwowano na rynku mleka. Od 2014 do połowy 2016 r. zarówno w Polsce, jak i UE następował bowiem systematyczny spadek cen mleka. Przeciętne ceny mleka, które rolnikom oferowały największe europejskie mleczarnie w czerwcu 2016 r. były niższe w porównaniu do czerwca 2014 r. o ponad 35\% (Parzonko, 2016a).

Cena mleka na rynku UE zależy od różnych czynników, z których najważniejsze to popyt i podaż mleka w płynie oraz głównie produkty mleczne i handel międzynarodowy na wspólnym rynku UE (Simo i in. 2016).

Niskie ceny mleka uwarunkowane były nadpodażą, jaka pojawiła się na rynku. Przyczyn tej sytuacji był wiele. $Z$ jednej strony Chiny, będące największym importerem na światowym rynku mleka i produktów mlecznych, silnie zmniejszyły popyt. Z drugiej możliwości zbytu ograniczone zostały przez rosyjskie embargo nałożone na produkty 
rolno-spożywczego. Jednocześnie likwidacja kwot mlecznych przyczyniła się w wielu krajach UE do zwiększenia produkcji mleka, co było zgodne $\mathrm{z}$ wcześniejszymi przewidywaniami ekspertów dotyczącymi zmian w produkcji mleka po zniesieniu kwot (Hamulczuk, Stańko, 2009; Świttyk, Wilczyński 2012).

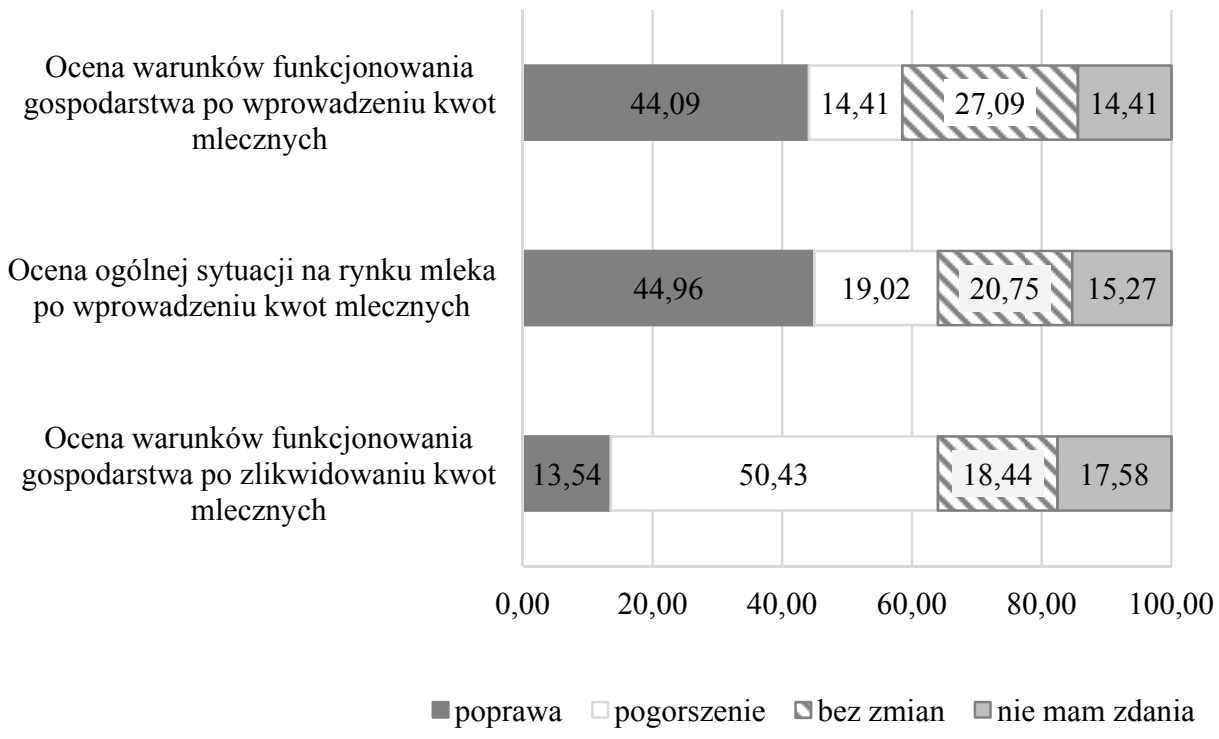

Rys. 3. Sytuacja na rynku mleka w opinii producentów rolnych

Fig. 3. The situation on the milk market in the farmers' opinion

Źródło: opracowanie własne na podstawie badań ankietowych.

Zbieg niekorzystnych - z perspektywy producentów mleka - okoliczności sprawił, że aż $61,96 \%$ respondentów wyraziło opinię, że na rynku mleka powinien być większy stopień interwencji (rys. 4). Jedynie 13,54\% badanych uważało, że nie powinno się ingerować w rynek, a ok. $1 / 4$ uznało obowiązujący poziom ingerencji za wystarczający. Trudna sytuacja wielu gospodarstw specjalizujących się $\mathrm{w}$ produkcji mleka po zniesieniu limitów produkcji skłoniła producentów rolnych do refleksji nad ich przyszłością. Przyczyną obaw jest głównie kwestia utrzymania odpowiedniego poziomu dochodów. W związku z tym różne były plany ankietowanych. Aż 54,76\% miało zamiar zwiększyć produkcję mleka, co przy nawet relatywnie niskich cenach pozwoliłoby uzyskać oczekiwany dochód. Jak wynika z badań przeprowadzonych przez Zeng i Gould $\left(2017^{8}\right)$ istnieje wiele wariantów umożliwiających wzrost produkcji mleka w gospodarstwach po zniesieniu kwot mlecznych. Jednym z nich jest powiększanie wielkości stada, czemu niekoniecznie musi towarzyszyć wzrost wydajności.

\footnotetext{
${ }^{8}$ http://www.aes.ac.uk/upload_area/member_documents/Shuwei_Zeng_Productivity\%20and\%20Quota\%20Aboliti on.pdf, dostęp: 10.10.2017
} 
Kolejne $38,90 \%$ badanych zakładało utrzymanie dotychczasowego poziomu produkcji. Niewielki odsetek ankietowanych $(2,02 \%)$ zadeklarował chęć ograniczania produkcji. Natomiast nieco ponad $4 \%$ objętych badaniem rolników zamierzało zaniechać produkcji mleka. W tej grupie przeważali rolnicy, którzy posiadali stada liczące średnio w roku do 20 sztuk krów.

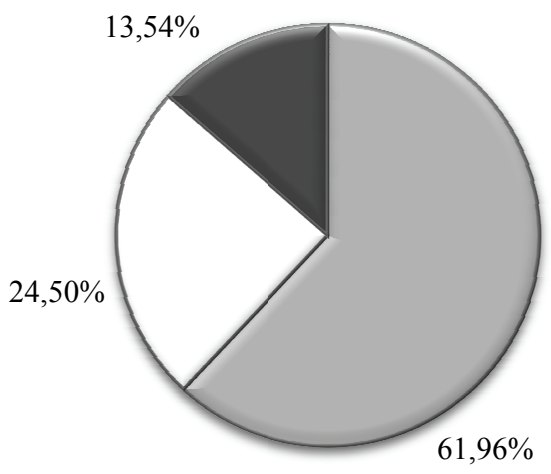

$\square$ większy stopień interwencji

$\square$ obecny poziom ingerencji jest

国nie powinno się ingerować

Rys. 4. Potrzeba interwencji na ryku w opinii producentów mleka

Fig. 4. The need for market intervention in the opinion of dairy farmers

Źródło: opracowanie własne na podstawie badań ankietowych.

Zaprezentowane informacje pozwalają przypuszczać, że w kolejnych latach będzie w Polsce postępował proces koncentracji produkcji mleka. Alternatywą dla rolników rezygnujących $\mathrm{z}$ tego kierunku produkcji może być chów bydła mięsnego. Przemawia za tym m.in. dostosowana do potrzeb takiej produkcji infrastruktura gospodarstwa, a także dotychczasowe doświadczenie i przygotowanie zawodowe producentów rolnych.

\section{Podsumowanie}

Niedoskonałości związane z funkcjonowaniem mechanizmów rynkowych są jedną z przyczyn skłaniających do podejmowania interwencji. Wolny rynek charakteryzuje się automatyzmem, będącym konsekwencją wolności gospodarczej. Ta z kolei przekłada się swobodę konkurencji, która pobudza produktywność, racjonalność gospodarowania i alokowania zasobów tam, gdzie mogą być najefektywniej wykorzystane. Wolny rynek nie jest jednak w stanie rozwiązać wszystkich problemów, $\mathrm{z}$ tego względu uznaje się za konieczne jego korygowanie. Jednym ze słabszych partnerów, w relacji do innych w gospodarce, jest rolnictwo. Dlatego uważa się, że wymaga ono interwencji państwa. Koncepcja ta realizowana jest $\mathrm{w}$ krajach UE $\mathrm{w}$ ramach wspólnej polityki rolnej. Zmieniające się uwarunkowania sprawiają jednak, że polityka ta ewoluuje. Jedną $z$ istotnych zmian, poddających sektor rolny większemu wpływowi rynku była likwidacja kwot mlecznych. 
Zniesieniu tego instrumentu, w celu większej liberalizacji unijnego rynku mleka, towarzyszyło wiele niekorzystnych okoliczności. Związane były one m.in. $\mathrm{z}$ wprowadzeniem rosyjskiego embarga na produkty rolno-spożywcze pochodzących z UE, czy też ograniczeniem ze strony Chin popytu na mleko i przetwory mleczne. Konsekwencją był niski poziom cen mleka. Problem ten dodatkowo pogłębił się w 2015 r. na skutek braku ograniczeń produkcji i doprowadził do nadpodaży na rynku. Fakt ten mógł zdecydować, że w opinii ponad połowy objętych badaniami producentów zniesienie kwot spowodowało pogorszenie warunków funkcjonowania ich gospodarstwa. W nawiązaniu do tego prawie $62 \%$ było zdania, że powinien być większy stopień interwencji.

Spodziewać się można, że w kolejnych latach liczba producentów mleka w naszym kraju nadal będzie się zmniejszać. Plany związanie z zaniechaniem produkcji mleka miało nieco ponad $4 \%$ badanych. Z kolei producenci mleka, którzy zamierzają kontynuować produkcję, w większości (54,73\%) planują jej zwiększenie.

\section{Literatura}

Baer-Nawrocka, A., Kiryluk-Dryjska, E. (2010). Konsekwencje zniesienia kwot mlecznych dla polskiego rolnictwa $\mathrm{z}$ uwzględnieniem zróżnicowania regionalnego (Consequences of milk quota abolition for the Polish agriculture with focus on the regional differentiation). Zagadnienia Ekonomiki Rolnej, 2(232), 62-74.

Czyżewski, A., Guth, M. (2016). Zróżnicowanie produkcji mleka w makroregionach Unii Europejskiej z wyróżnieniem Polski (Diversification of milk production in the macro-regions of the European Union with focus on Poland). PWN, Warszawa.

Gornowicz, M. (2003). Polskie mleczarstwo w aspekcie konkurencyjności na jednolitym rynku Unii Europejskiej (Polish dairy industry in the aspect of competitiveness on the European Union market). UWM, Olsztyn.

Grochowska, R. (2003). Wspólna organizacja rynku mleka i produktów mlecznych w Unii Europejskiej (Common organization of the milk and milk products market in the European Union). UKIE, Warszawa.

Hamulczuk, M., Stańko, S. (2009). Ekonomiczne skutki likwidacji kwot mlecznych w Unii Europejskiej - wyniki symulacji z wykorzystaniem modelu AGMEMOD (Economic analysis of the effect of the European Union milk quota system abolition - simulation results based on the AGMEMOD model). Zagadnienia Ekonomiki Rolnej, 4, 3-20.

Parzonko, A. (2013). Gospodarstwa mleczne w perspektywie liberalizacji polityki rolnej UE w latach 2014-2020 (Dairy farms in a perspective of liberalisation of agricultural policy in the EU in 2014-2020). Zagadnienia Ekonomiki Rolnej, 1(334), 118-132.

Parzonko, A. (2014). Regionalne zmiany produkcji mleka w Polsce - stan i przyczyny (Regional changes in milk production in Poland - state and reasons). Roczniki Ekonomiczne Kujawsko-Pomorskiej Szkoły Wyższej w Bydgoszczy, 7, 218-233.

Parzonko, A. (2016a). Polscy producenci mleka na tle Europy (Polish milk producers against the background of Europe). Top Agrar Polska 7, 4-8.

Parzonko, A. (2016b). Rola „drobnych” gospodarstw mlecznych w paradygmacie zrównoważonego rozwoju (The role of "small" dairy farms in the paradigm of sustainable development). Problemy Drobnych Gospodarstw Rolnych, 2, 63-84.

Report from the Commission to the European Parliament and the council. Development of the dairy market situation and the operation of the "Milk Package" provisions. (2016).

Rozporządzenie Parlamentu Europejskiego i Rady (UE) nr 261/2012 z dnia 14 marca 2012 r. w sprawie zmiany rozporządzenia (WE) nr 1234/2007 w odniesieniu do stosunków umownych w sektorze mleka i przetworów mlecznych.

Sadowski, A., Michalczak, D. (2015). Przemiany gospodarstw specjalizujących się w produkcji mleka w wybranych krajach Unii Europejskiej (Transformation of dairy farms in selected EU countries). Problemy Rolnictwa Światowego, 15(3), 132-141.

Seremak-Bulge, J., Roman, M. (2016). Sytuacja na światowym rynku mleka i jej wpływ na polski rynek i jego możliwości rozwojowe (The situation on the global milk market and its impact on the Polish market and its development opportunities). W: S. Stańko (red.). Sytuacja na światowych rynkach mięsa i produktów 


\section{K. Babuchowska}

mleczarskich oraz jej wpływ na rynek krajowy i możliwości jego rozwoju. Monografie Programu Wieloletniego nr 31 (s. 105-154). IERiGŻ PIB, Warszawa.

Simo, D., Mura, L., Buleca, J. (2016). Assesment of milk production competitiveness of the Slovak Republic within the EU-27 countries. Agricultural Economics - Czech, 62, 482-492.

Szajner, P. (2014). Wahania sezonowe na rynku mleka w Polsce i UE-15 (Seasonal fluctuations on dairy market in Poland and UE-15). Problemy Rolnictwa Światowego, 14(1), 120-129.

Śmigla, M. (2013). Stan i perspektywy rozwoju rynku mleka w Unii Europejskiej w świetle zniesienia kwot mlecznych (The condition and prospects for development of milk market in the European Union in the light of abolition of the milk quota system). Folia Pomerane Universitatis Technologiae Stetinensis, Oeconomia, 299(70), 237-250.

Świtłyk, M., Wilczyński, A. (2012). Sytuacja ekonomiczna gospodarstw mlecznych po likwidacji systemu kwotowania produkcji mleka (Economic situation of dairy farms after liquidation of the system of milk production quotas). Wieś $i$ Rolnictwo, 1(154), 85-97.

Zeng, S., Gould, B. (2017). EU Milk Quota Abolition: Has the Productivity of Irish Dairy Farms Been Impacted? Pobrano z: http://www.aes.ac.uk/upload_area/member_documents/Shuwei_Zeng_Productivity\%20and\%20 Quota\%20Abolition.pdf>

Do cytowania / For citation:

Babuchowska K. (2020). Wpływ zniesienia kwot mlecznych na funkcjonowanie gospodarstw specjalizujących się w produkcji mleka. Problemy Rolnictwa Światowego, 20(1), 5-14; DOI: $10.22630 /$ PRS.2020.20.1.1

Babuchowska K. (2020). Impact of the Abolition of Milk Quotas on the Functioning of Dairy Farms (in Polish). Problems of World Agriculture, 20(1), 5-14; DOI: 10.22630/PRS.2020.20.1.1 